\title{
Otomatisasi Proses Online Stock Opname pada Aplikasi Inventaris Barang untuk Multi Lokasi Pergudangan
}

\author{
http://dx.doi.org/10.28932/jutisi.v7i2.3832 \\ Riwayat Artikel \\ Received: 23 Juli 2021 | Final Revision: 29 Juli 2021 | Accepted: 30 Juli 2021 \\ Laura Mahendratta Tjahjono ${ }^{\bowtie \# 1}$, Adi Suryaputra Paramita ${ }^{* 2}$ \\ ${ }^{1}$ Program Studi Informatika, Universitas Ciputra \\ Citraland CBD Boulevard, Made, Kec. Sambikerep Surabaya, Jawa Timur 60219 \\ laura@ciputra.ac.id \\ ${ }^{2}$ Program Studi Sistem Informasi, Universitas Ciputra \\ Citraland CBD Boulevard, Made, Kec. Sambikerep Surabaya, Jawa Timur 60219 \\ adi.suryaputra@ciputra.ac.id
}

\begin{abstract}
The process of stock opname of goods in a business is something that must be done regularly to control the business assets. The stock opname process generally requires a lot of money and time, especially in businesses that have many branch locations. During the implementation of stock opname, sales transactions are usually stopped so that the stock does not change. As a result, the longer the time for this process is required, the greater the loss. In addition, extra costs are also incurred when the implementing manager is sent to each branch location where the stock opname will be carried out. Due to the high costs and losses incurred, this stock opname is usually only done a few times a year. On the other hand, the low frequency of stock opname has an impact on increasing business losses due to loss of assets that cannot be detected early. This study aims to increase the effectiveness of the stock opname process to minimize losses that occur during the stocktaking process or losses due to delays in handling the loss of goods assets. The results of this study indicate that the new system design allows the stock opname process to be carried out remotely without the presence of a manager and without stopping sales transactions, so as to reduce operational costs. The frequency of stock opname can also be carried out more frequently so that if there is a loss of assets, it can be immediately identified and action is taken to avoid high business losses. The result of software testing using the Blackbox Testing method shows that the application can run well and the result of User Acceptance Testing shows the acceptance of respondents at $87 \%$, which means that respondents accept the solutions offered well.
\end{abstract}

Keywords — automation; inventory; stock opname; user acceptance testing; web based application.

\section{PENDAHULUAN}

Proses stock opname barang dalam sebuah bisnis retail merupakan hal yang wajib dilakukan secara berkala untuk mengontrol aset dari bisnis [1]. Stock opname merupakan sebuah kegiatan perhitungan jumlah barang yang tersedia di lapangan dengan tujuan untuk mengontrol kesesuaian antara jumlah barang secara fisik dan data yang tercatat di sistem. Seperti yang dijelaskan pada penelitian sebelumnya, kontrol aset bisnis ini sangat diperlukan untuk mengetahui kecocokan jumlah stok barang secara fisik dengan data yang tercatat di system serta untuk menghindari terjadinya kerugian akibat kehilangan. [2][3].

Penelitian-penelitian sebelumnya menunjukkan bahwa proses stock opname barang ini sudah sangat terbantu dengan digunakannya aplikasi dengan fitur stock opname yang user friendly dalam bentuk web application, desktop application atau android application. Pada beberapa penelitian, proses ini juga semakin dipermudah dengan disediakannya fitur pemindaian barcode yang dapat meningkatkan efektifitas proses stock opname [4][5].

Namun demikian, meski sudah menggunakan aplikasi proses stock opname yang biasa dijalankan saat ini masih menyisakan banyak permasalahan baik dari segi waktu maupun tingginya biaya. Proses stock opname umumnya 
dilaksanakan dengan cara pemilik bisnis datang langsung untuk melakukan cek kondisi jumlah barang, atau dengan mendatangkan manajer ke lokasi gudang / cabang took yang hendak dihitung stok barangnya. Pemilik bisnis atau manajer terkadang perlu turun langsung ke lapangan untuk menghindari ketidakjujuran yang dilakukan pegawai saat perhitungan stok. Hal ini tentunya mengakibatkan meningkatnya biaya operasional untuk transportasi dan akomodasi bagi pemilik atau manajer tersebut, terutama bila lokasi toko atau gudang berada di kota yang berbeda. Pada saat proses tersebut, manajer harus mengunjungi lokasi secara langsung sehingga tugas utamanya sering kali tertunda untuk beberapa hari.

Selain itu, manajer atau pegawai yang bertugas melakukan stock opname harus memiliki pemahaman terkait proses stock opname dan harus dilatih terkait langkah yang harus dilakukan dan diminta untuk melakukan demonstrasi kembali untuk meminimalkan kesalahan [6]. Proses pelatihan pada manajer ini tentunya membutuhkan biaya dan juga waktu.

Proses stock opname dengan cara ini juga membutuhkan waktu di lokasi yang tidak sedikit. Durasi pelaksanaan sangat tergantung dari banyaknya jumlah barang yang harus dihitung. Biasanya saat pelaksanaan stock opname toko atau gudang akan menghentikan operasional penjualannya, atau dengan kata lain menutup toko selama proses pelaksanaan agar jumlah stok barang tidak berubah-ubah. Semakin lama operasional penjualan dihentikan, maka kerugian juga akan semakin besar. Dengan alasan tersebut, banyak bisnis yang melakukan stock opname ini hanya beberapa kali saja dalam setahun.

Frekuensi stock opname yang cukup rendah ini tentunya tidak ideal dan berakibat buruk pada bisnis. Dengan frekuensi rendah ini, pemilik bisnis akan terlambat untuk bisa mengetahui ketidaksesuaian jumlah stok barang, yaitu setelah beberapa bulan atau bahkan baru pada akhir tahun. Tentunya akan sulit untuk melacak kembali kemana hilangnya barang atau untuk mengambil keputusan bisnis yang cepat dan tepat. Selaras dengan penelitian sebelumnya yang menyebutkan bahwa proses pengadaan barang kembali juga tentunya akan terdampak dengan data yang tidak akurat tersebut [7].

Berdasarkan permasalahan yang ditemui tersebut, maka dalam penelitian ini dikembangkan fitur unggulan dalam aplikasi stock opname yang ada, dimana fitur ini akan memungkinkan otomatisasi proses stock opname tanpa perlunya kehadiran langsung manajer maupun pemilik bisnis sehingga dapat mengurangi biaya operasional. Selain itu fitur unggulan ini dibuat agar dapat meningkatkan frekuensi pelaksanaan stock opname, sehingga pemilik bisnis dapat segera mengetahui permasalahan di lapangan dan segera mengambil keputusan dan tindakan guna meminimalkan kerugian bisnis.

\section{Metode Peneltitian}

Dalam penelitian ini digunakan metode waterfall sesuai dengan penjabaran dari buku Sukamto 2014 [5]. Metode waterfall membagi proses pengembangan perangkat lunak menjadi empat bagian, yaitu proses analisis, desain, pengkodean, pengujian seperti terlihat pada Gambar 1 [8].

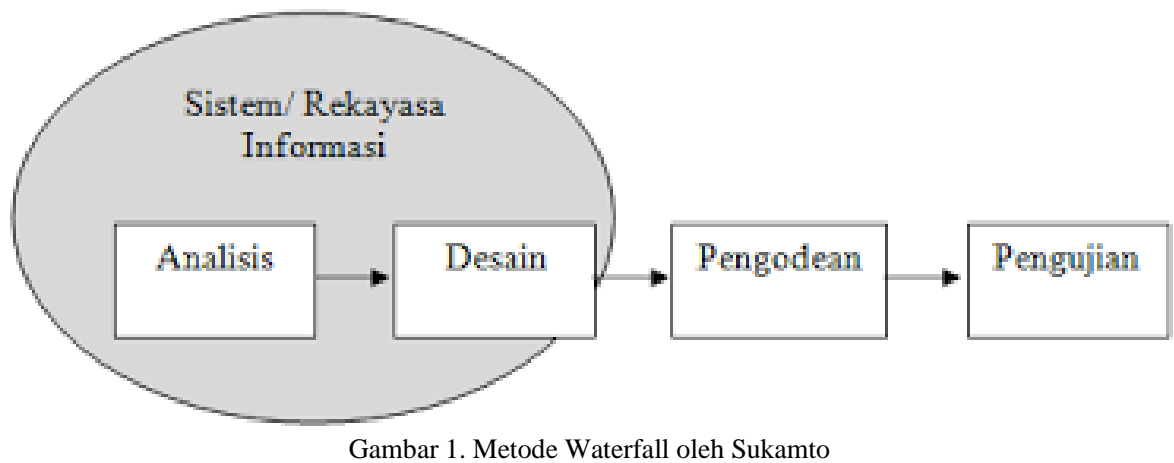

Pada proses analisis akan dilakukan pengamatan pada prosedur atau proses yang terjadi di lapangan. Proses ini diperlukan untuk mengidentifikasi permasalahan yang terjadi dan menentukan solusi yang sesuai. Solusi yang disarankan dari temuan permasalahan di lapangan akan direalisasikan dalam proses desain sistem. Dalam proses desain ini akan dirancang desain sistem yang paling ideal namun tetap dengan memperhatikan kebutuhan dan kondisi di lapangan. Selanjutnya setelah desain sistem selesai, maka akan masuk ke proses pengkodean. Di dalam proses ini, mulai dilakukan pemrograman untuk sistem yang sudah didesain hingga tercipta sebuah aplikasi. Langkah terakhir adalah proses pengujian, dimana aplikasi yang telah dibuat akan diuji apakah mampu menjadi solusi dari permasalahan yang ada.

Penjabaran lebih detail untuk masing-masing tahap dalam penelitian ini adalah sebagai berikut:

\section{A. Analisis}

Dalam fase analisis ini digunakan metode penelitian kualitatif untuk mengumpulkan data. Penelitian data kualitatif dilakukan dengan cara observasi dan wawancara. 
Observasi dilakukan dengan cara mengunjungi langsung kantor dan toko yang memiliki lokasi berbeda. Dari hasil observasi ini ditemukan permasalahan pada kesesuaian jumlah stok barang yang tercatat di kantor dan jumlah realita yang ada di gudang toko.

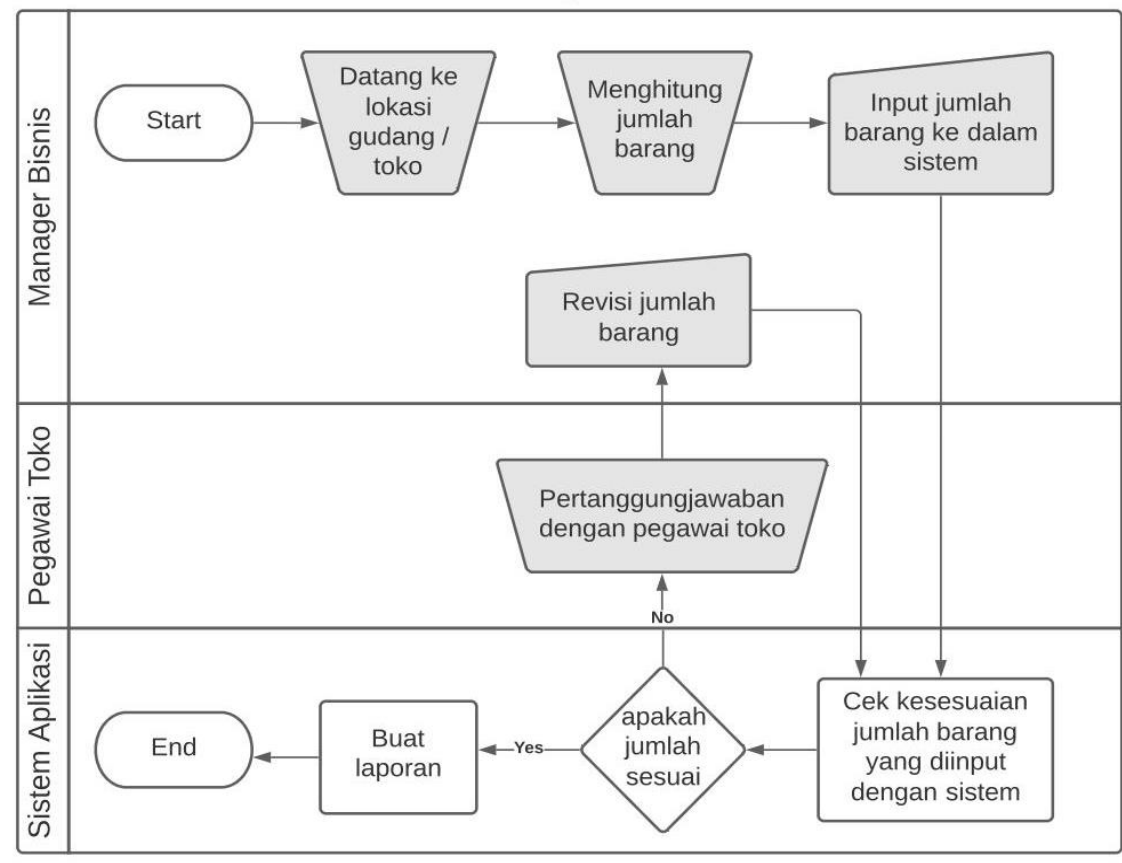

Gambar 2. Activity diagram: proses stock opname sebelum optimasi.

Pada proses wawancara terhadap narasumber dilakukan wawancara terhadap pegawai admin kantor dan pegawai toko. Dari wawancara ini ditemukan permasalahan yang mengakibatkan ketidaksesuaian jumlah stok barang. Dari hasil wawancara ini diketahui proses stock opname yang selama ini dilakukan seperti yang terlihat pada activity diagram di Gambar 2. Activity diagram ini menunjukkan bahwa manajer harus datang ke lokasi toko untuk menghitung jumlah barang, memasukkan jumlah barang ke system dan melihat laporan kesesuaian jumlah stok barang dari sistem. Apabila terjadi ketidaksesuaian maka manajer akan melakukan perhitungan ulang sebelum berkoordinasi dengan pegawai toko setempat terkait konsekuensi yang harus dipertanggungjawabkan.

Karena besarnya biaya operasional, maka manajer yang datang ke lokasi biasanya hanya satu atau maksimal dua orang. Akibatnya apabila jumlah barang banyak maka proses stock opname ini berlangsung cukup lama dan transaksi penjualan juga berhenti cukup lama. Hal ini mengakibatkan kerugian lainnya sehingga untuk meminimalkan kerugian tersebut proses stock opname ini tidak dilakukan terlalu sering. Namun di lain pihak, hal ini berakibat pada besarnya ketidak-cocokan jumlah stok barang pada sistem dengan kenyataan di lapangan, sehingga harus banyak dilakukan revisi jumlah barang dan berakibat pada kerugian.

Temuan di lapangan ini kemudian dijadikan salah satu dasar pertimbangan dalam perancangan solusi untuk memperbaiki prosedur stock opname dan pengembangan sistem aplikasi.

\section{B. Desain Sistem}

Berdasarkan hasil analisis maka dirancang sebuah solusi terkait proses stock opname yang dapat meminimalkan kerugian bisnis. Sebagai langkah awal, dilakukan perubahan hak akses pegawai pada sistem aplikasi sehingga pegawai toko tidak bisa lagi melihat jumlah stok yang tertera di dalam sistem aplikasi. Hal ini diperlukan untuk menghindari adanya kecurangan dalam proses stock opname nantinya. 


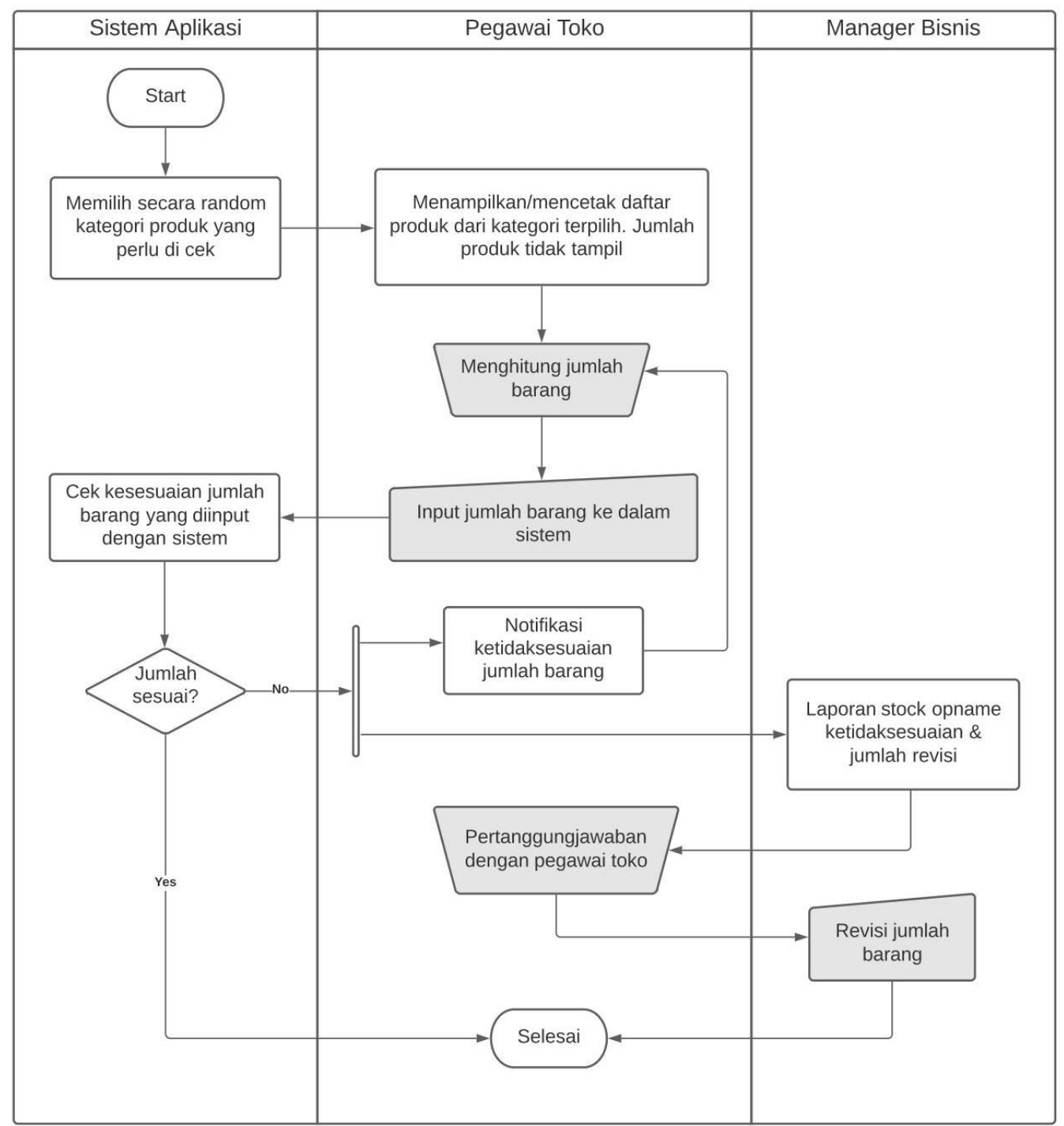

Gambar 3. Activity diagram: proses stock opname setelah dilakukan optimasi

Dalam desain sistem yang baru seperti yang dapat dilihat pada activity diagram di Gambar 3. Dalam desain sistem ini terdapat dua aktor sistem yaitu manajer dan pegawai toko. Manajer memiliki hak akses untuk melihat laporan hasil stock opname, mengambil keputusan/tindakan terkait selisih jumlah barang bila terjadi selisih serta melakukan revisi penyesuaian jumlah barang. Sedang tugas dan hak akses pegawai toko adalah melakukan proses perhitungan stok yang awalnya harus dilakukan oleh manajer. Pegawai toko yang harus melakukan perhitungan jumlah fisik barang dan memasukkan hasil perhitungan ke dalam system. Semua ini dilakukan tanpa pegawai toko dapat melihat jumlah stok yang tersimpan di system. Hal ini diperlukan agar pegawai toko tidak bisa melakukan kecurangan dengan cara memasukkan jumlah barang seperti yang tertera dalam sistem. Pegawai toko harus melakukan perhitungan fisik untuk dapat memasukkan jumlah barang yang sesuai.

Sistem akan menyediakan formulir berisi daftar produk dimana pegawai toko dapat mengisi jumlah stok produk tersebut setelah sebelumnya menghitung jumlah stok di gudang. Perlu diketahui bahwa disini pegawai toko tidak bisa melihat berapa jumlah stok barang tersebut di sistem. Selanjutnya system akan melakukan pencocokan dan mengeluarkan laporan. Apabila terjadi ketidaksesuaian, maka pegawai toko dapat melihat notifikasi barang mana yang tidak sesuai jumlahnya. Namun pegawai toko tetap tidak bisa melihat berapa jumlah seharusnya. Pegawai toko dapat melakukan perhitungan ulang dan memasukkan kembali jumlah barang.

Apabila proses stock opname selesai dan ada produk yang jumlah stok tidak sesuai dengan jumlah yang tersimpan di sistem, maka sistem akan secara otomatis membuat notifikasi yang ditampilkan ke aplikasi pegawai toko dan juga ke 
aplikasi manager. Notifikasi yang muncul pada layar pegawai toko hanyalah berupa pemberitahuan bahwa jumlah tidak sesuai, sedangkan pada layar manajer akan muncul jumlah yang tertera di sistem, jumlah yang di-input dan selisihnya. Manager hanya perlu melihat laporan ini untuk mengetahui apabila terjadi ketidaksesuaian yang memerlukan tindakan penyesuaian.

Saat memperoleh notifikasi ini, pegawai toko dapat melakukan pengecekan ulang jumlah produk di lapangan dan melakukan revisi jumlah stok. Semua revisi yang dilakukan ini akan tersimpan di sejarah stock opname sehingga manager dapat melakukan pengecekan. Apabila pada akhirnya jumlah stok tetap tidak sesuai, maka manajer dapat segera berkoordinasi dengan pegawai toko terkait konsekuensinya dan menyesuaikan kembali jumlah stok di aplikasi agar sesuai dengan kondisi di lapangan.

Selain itu proses stock opname tidak akan mengharuskan pegawai untuk menghitung seluruh produk sekaligus, tapi sistem secara berkala akan memilih kategori produk yang perlu dilakukan stock opname. Dalam sekali proses stock opname akan dipilih hanya beberapa kategori saja tergantung total jumlah barang yang ada di kategori tersebut. Dengan demikian proses stock opname tidak membutuhkan waktu yang lama namun bisa sering dilakukan. Proses stock opname ini bisa dilakukan sesering mungkin, bisa sebulan sekali, seminggu sekali bahkan bisa setiap hari. Dengan demikian apabila terjadi ketidaksesuaian maka dapat segera diambil keputusan dan tindakan.

Sistem aplikasi ini tentunya harus bisa diakses secara online sehingga memungkinkan manajer untuk melakukan pengecekan stok dari jarak jauh. Karena itu sistem aplikasi ini idealnya dibuat berupa aplikasi berbasis website yang dapat diakses oleh pegawai toko dari komputer toko tanpa memerlukan instalasi khusus yang rumit. Berikut beberapa elemen penting yang terkandung dalam solusi yang didesain pada penelitian ini:

1. Proses stock opname harus bisa dilakukan dari jarak jauh

2. Proses stock opname harus bisa dilakukan oleh pegawai toko setempat tanpa kehadiran manajer

3. Proses stock opname jarak jauh harus bisa menghindari kemungkinan kecurangan data

4. Proses stock opname harus dapat dilakukan sesering mungkin

5. Proses stock opname harus dapat dilakukan tanpa mengharuskan toko menghentikan operasional penjualan

\section{Pengkodean}

Pada fase pengkodean ditentukan infrastruktur yang diperlukan untuk pengembangan aplikasi. Berdasarkan pertimbangan kemudahan instalasi, maka dipilih aplikasi berupa website dinamis yang menggunakan database.

Database yang digunakan adalah MySQL dan bahasa pemrograman yang digunakan adalah PHP untuk mendukung HTML dan CSS. Untuk penyimpanan file website ini digunakan hosting dari provider yang sudah ada.

1) Rancangan ERD: Pada fase awal proses pengembangan yang pertama dilakukan adalah merancang desain database sesuai dengan kebutuhan. Dalam merancang desain database ini digunakan ERD (Entity Relationship Diagram). ERD sendiri adalah sebuah cara untuk membuat pemodelan data dalam sebuah sistem aplikasi. ERD mengatur dan menampilkan data secara terorganisasi dalam bentuk entitas serta menampilkan hubungan antar entitas tersebut [9].

Entitas yang dikenal dalam ERD ini tidak lain adalah tabel yang berisi kolom-kolom data. Kolom dalam ERD ini dikenal dengan istilah attribute. Dalam ERD, setiap entitas harus memiliki satu attribute yang akan ditunjuk sebagai primary key. Data primary key ini nantinya yang akan digunakan untuk mengidentifikasi setiap baris data dalam tabel terkait. Selain itu, primary key ini juga digunakan untuk menciptakan relasi antar entitas atau dengan kata lain menghubungkan satu tabel dengan tabel lainnya.

Rancangan ERD database untuk aplikasi dalam penelitian ini dapat dilihat pada Gambar 4. Di dalam ERD ini dapat dilihat tabel yang menyimpan data produk, stok produk, transaksi penjualan, transaksi pembelian, hak akses user dan data stock opname. Proses stock opname membutuhkan tabel product_category, product_brand, product, product_stock, product_check_stock dan product_check_stock_detail. Di dalam tabel product ini terdapat attribute yang menyimpan data kapan terakhir stock opname atas produk tersebut dilakukan. Di dalam tabel product_check_stock tersimpan data kapan stock opname dilakukan dan siapa user yang melakukan proses tersebut. Sedangkan produk apa saja yang dihitung dalam proses stock opname tersebut berikut hasilnya disimpan dalam tabel product_check_stock_detail. Untuk pencocokan data, sistem akan mencocokan jumlah stok yang di-input di tabel product_check_stock_detail dengan jumlah stok yang tersimpan di tabel product_stock. 


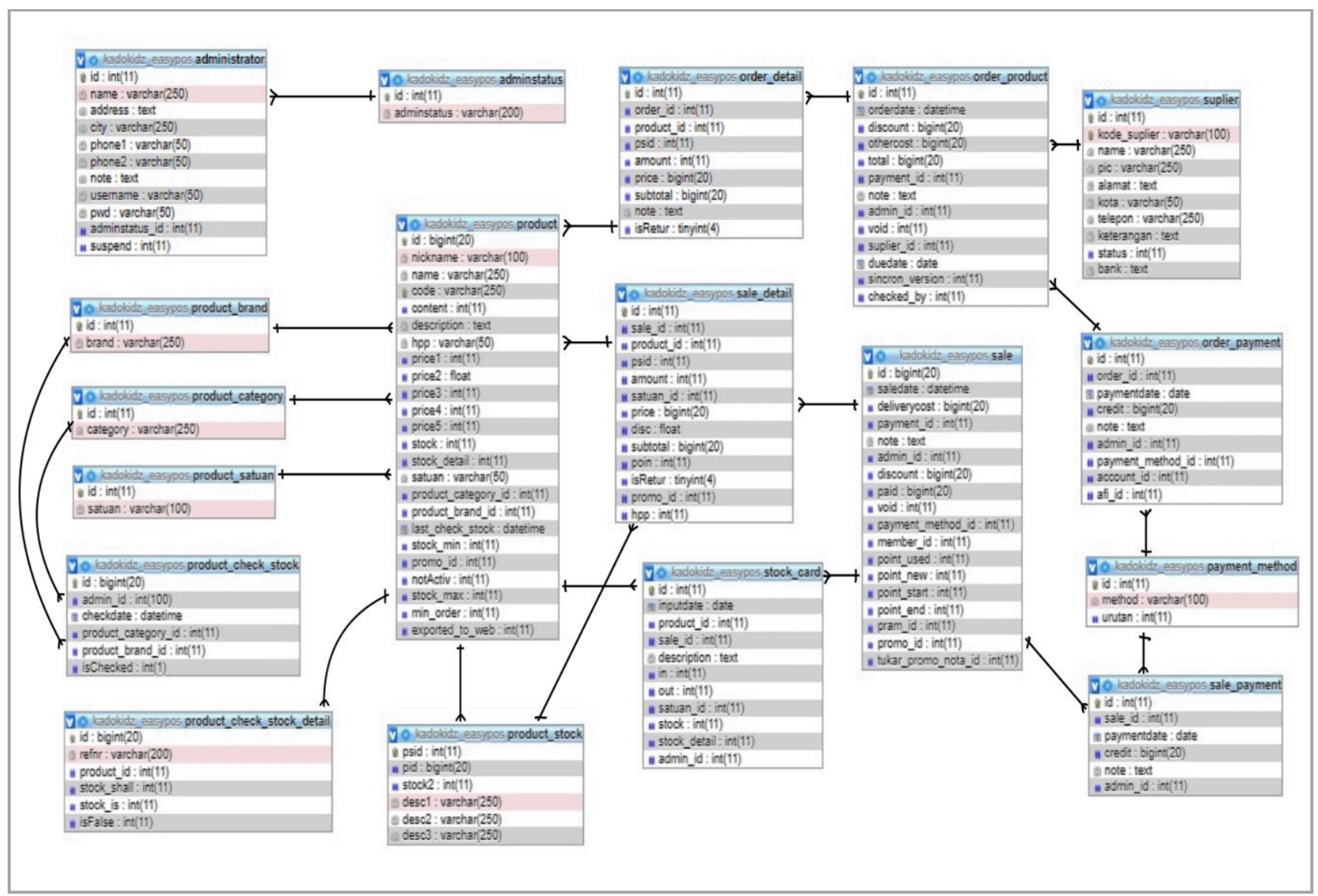

Gambar 4. Rancangan Database

2) Database MySQL: Selanjutnya setelah rancangan database selesai dibuat maka database diimplementasikan dengan menggunakan MySQL. MySQL adalah sebuah DBMS (Database Management System) yang berguna untuk menyimpan data secara fisik [10]. MySQL menggunakan bahasa pemrograman SQL yang dikembangkan oleh Ted Codd di era tahun 1970 untuk menjalankan perintah pengolahan data. Perintah pengolahan data ini mencakup antara lain [11]: perintah data query untuk mengambil dan menampilkan data dari database, data manipulation untuk menambah, mengubah, menghapus data dan mengurutkan data, data identity untuk mengkategorikan data berdasarkan jenisnya serta mengatur hubungan antar data, dan terakhir perintah data access control yang berguna untuk mengatur siapa saja yang memiliki hak untuk melakukan akses data guna melindungi keamanan data.

3) HTML \& CSS: Langkah selanjutnya dalam pengembangan aplikasi ini adalah merancang user interface yang akan ditampilkan kepada pengguna. Aplikasi ini dibuat berupa website yang menggunakan HTML dan CSS untuk pembuatan tampilannya. HTML (Hypertext Markup Language) adalah script pemrograman yang biasa digunakan untuk membuat website guna menampilkan informasi di dalam halaman website dan menentukan struktur halaman serta navigasi [12]. Sedangkan untuk memperindah tampilan digunakan CSS (Cascading Style Sheets). CSS selain digunakan untuk memperindah tampilan juga dapat digunakan untuk mengatur layout halaman menjadi responsive sehingga tampilan website tetap menarik saat diakses di berbagai jenis gawai, misalkan dibuka menggunakan komputer desktop, gawai tablet maupun handphone [12]. Dengan menggunakan CSS, konten dan desain dari sebuah halaman website dapat dibedakan dengan mudah.

4) PHP (Hypertext Preprocessor): untuk pengembangan aplikasi ini digunakan juga bahasa pemrograman PHP yang digunakan bersamaan dengan HTML pada pemrograman website. PHP adalah bahasa pemrograman yang digunakan untuk mengolah data di sisi server, seperti menampilkan, menyimpan, mengubah dan menghapus data dari database dan mengirimkan hasilnya ke sisi client yaitu aplikasi browser [13]. Dengan menggunakan PHP maka sebuah website dapat dibuat menjadi bersifat dinamis, yang artinya website dapat menerima data dari pengunjung serta menampilkan data sesuai 
permintaan dari pengunjung. PHP akan menerima masukan data dari pengunjung kemudian mengolahnya dan menyimpan ke database. Pada saat pengunjung mengirimkan permintaan data tertentu, PHP akan menjalankan perintah SQL query untuk mengambil data dari database. Dari sini dapat dilihat bahwa peran PHP sangat penting untuk membuat website menampilkan data secara dinamis [14].

Berikut adalah tampilan hasil implementasi website yang sudah diimplementasikan dengan menggunakan database MySQL, HTML, CSS dan PHP:

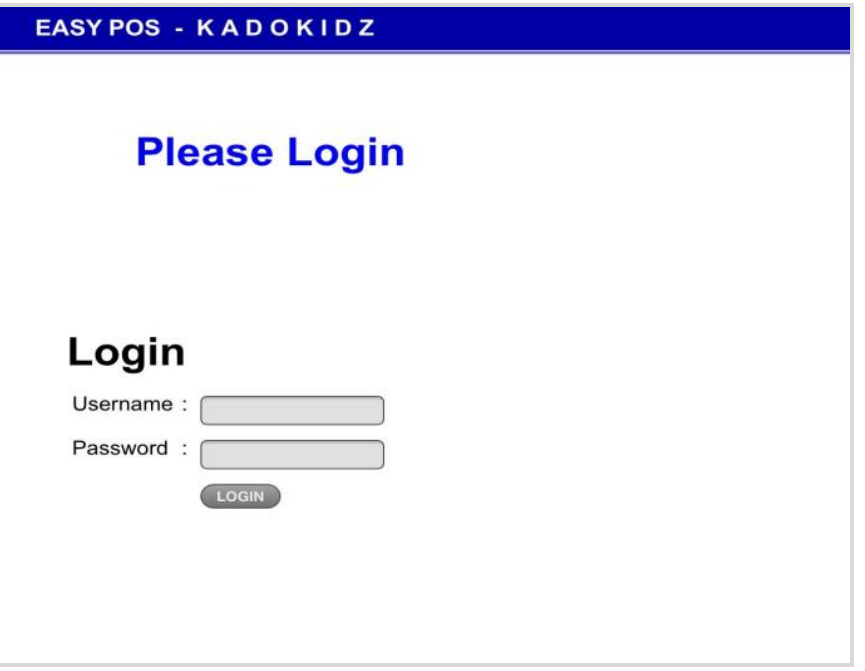

Gambar 5. Halaman login aplikasi website

Gambar 5 adalah tampilan awal dari aplikasi. Di halaman ini baik pegawai toko maupun manajer toko perlu melakukan login untuk dapat mengakses data dan melakukan perubahan pada data ataupun hanya sekedar melihat laporan.

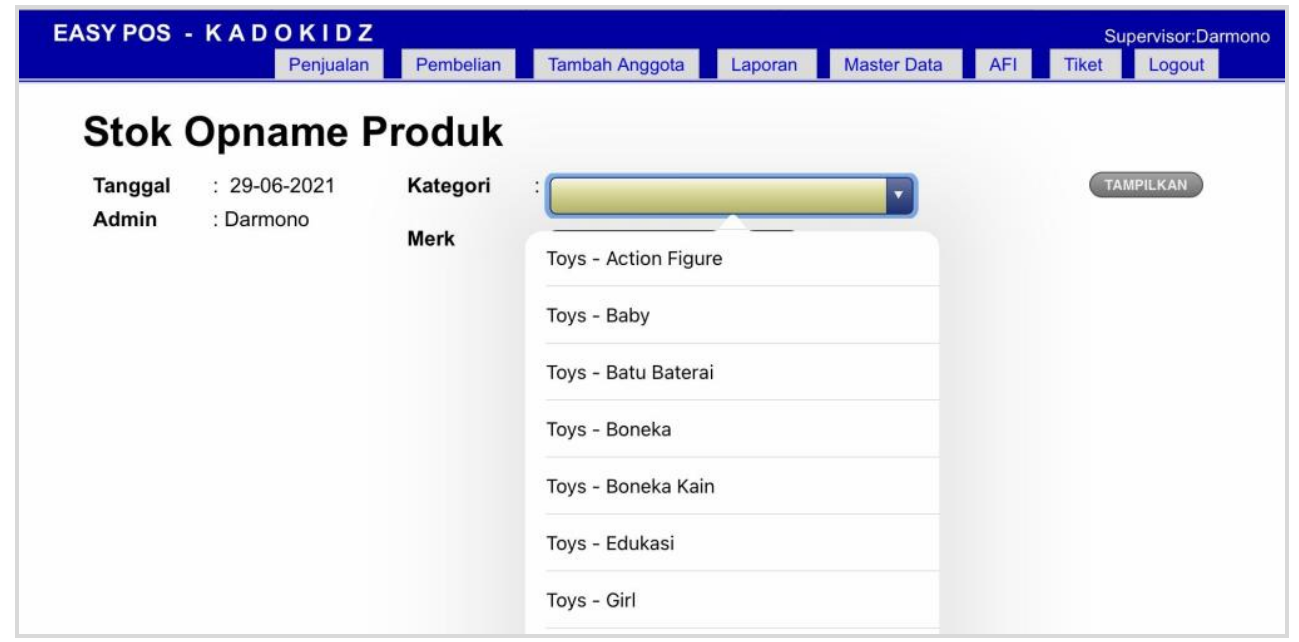

Gambar 6. Halaman stock opname: pemilihan produk berdasarkan kategori

Gambar 6 menampilkan halaman stock opname. Di halaman ini pegawai toko dapat memilih produk yang ingin di stok berdasarkan kategori produk. 


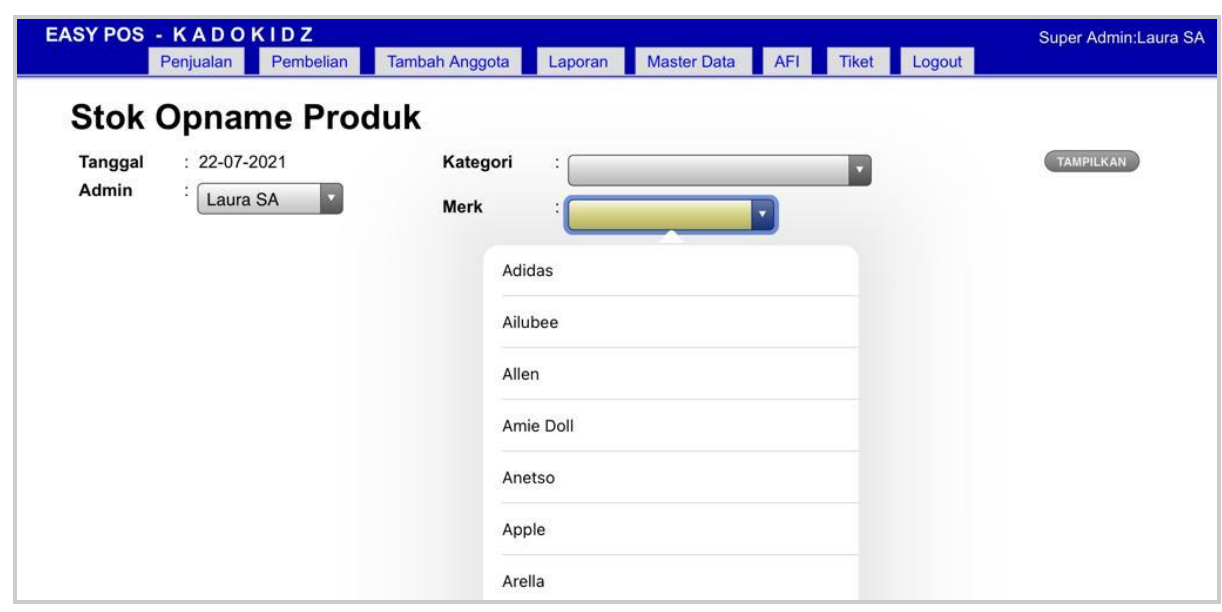

Gambar 7. Halaman stock opname: pemilihan produk berdasarkan merek

Sedangkan pada Gambar 7 ditampilkan cara pegawai toko memilih produk berdasarkan merek produk yang hendak di cek jumlah ketersediaan barangnya. Pilihan kategori produk dan merek produk ini diambil dari data yang sebelumnya sudah tersimpan di database.

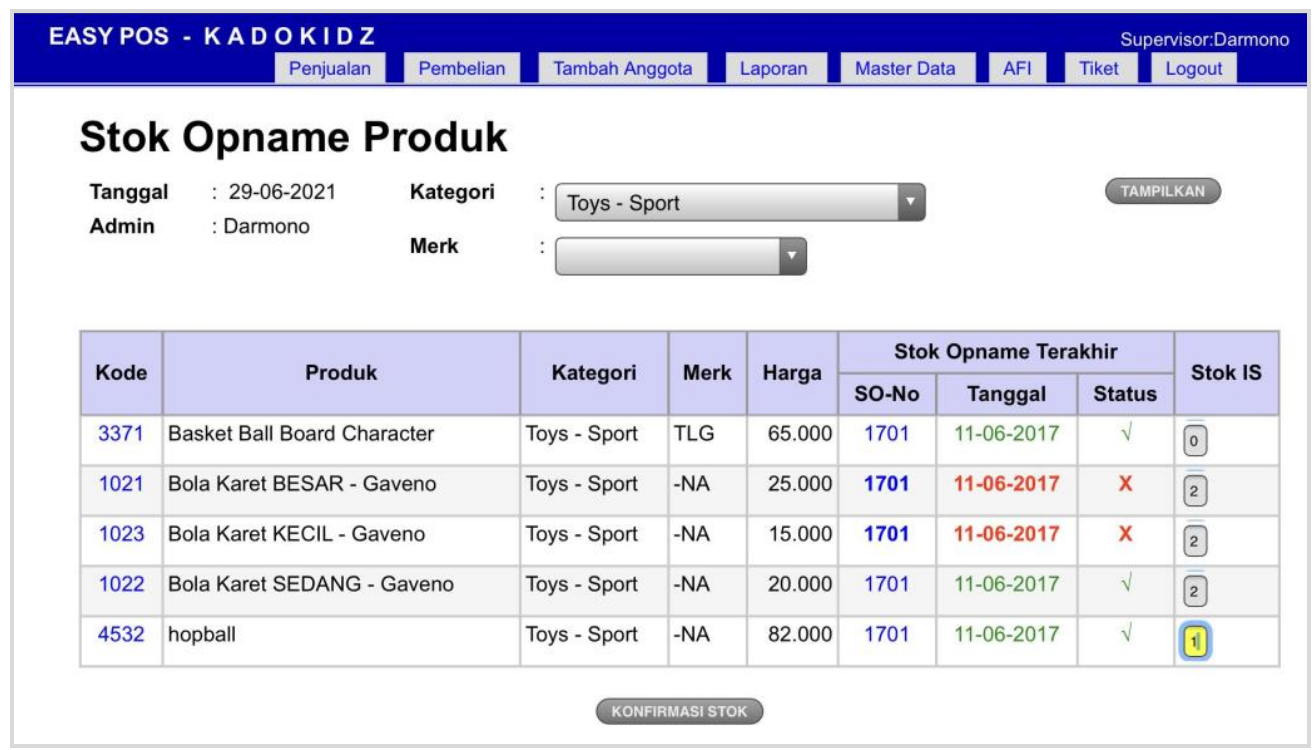

Gambar 8. Halaman stock opname

Selanjutnya pada Gambar 8 dapat dilihat bahwa setelah kategori atau merek produk dipilih, maka akan ditampilkan produk sesuai dengan kategori atau merek tersebut. Dapat dilihat disini bahwa pegawai toko tidak dapat melihat berapa jumlah stok produk yang ada di sistem. Pegawai toko hanya dapat melihat data berupa harga dan kapan stock opname terakhir dilakukan.

Warna pada keterangan tanggal terakhir stock opname dilakukan menunjukkan status kesesuaian jumlah barang. Apabila berwarna hijau, maka artinya pada stock opname sebelumnya jumlah barang di gudang dan di sistem sudah sesuai. Sebaliknya bila berwarna merah maka artinya pada stock opname terakhir terdapat ketidaksesuaian jumlah barang di gudang dan yang tertera di sistem.

Pegawai toko dapat melihat juga laporan dari stock opname sebelumnya untuk mengetahui siapa yang melakukan stock opname tersebut. 


\section{EASY POS - KADOKIDZ \\ Penjualan Pembelian Tambah Anggota Laporan Master Data AFI Tiket Logout}

\section{Stok Opname SO-1819}

$\begin{array}{ll}\text { Admin } & : \text { Darmono } \\ \text { Tanggal } & : \text { 29-06-2021 14:35 } \\ \text { Kategori / Merk } & : \text { Toys - Sport } \\ \text { Status } & : \text { SALAH }\end{array}$

Cek stok produk ada yang TIDAK SESUAI. Silahkan ulangi pengecekan stok.

Laporkan hasil cek ulang secara manual (tertulis).

\begin{tabular}{|c|c|c|c|c|c|c|c|c|}
\hline \multirow{2}{*}{ Kode } & \multirow{2}{*}{ Produk } & \multirow{2}{*}{ Kategori } & \multirow{2}{*}{ Merk } & \multirow{2}{*}{ Harga } & \multicolumn{3}{|c|}{ Stok Opname Terakhir } & \multirow{2}{*}{ Stok IS } \\
\hline & & & & & SO-No & Tanggal & Status & \\
\hline 4366 & B/O Game Pancing 15 Ikan + 4 Kail & Toys - Sport & $-N A$ & 65.000 & 1701 & $11-06-2017$ & $\sqrt{ }$ & 0 \\
\hline 3371 & Basket Ball Board Character & Toys - Sport & TLG & 65.000 & 1701 & 11-06-2017 & $\sqrt{ }$ & 0 \\
\hline 1021 & Bola Karet BESAR - Gaveno & Toys - Sport & $-\mathrm{NA}$ & 25.000 & 1701 & $11-06-2017$ & $\mathrm{x}$ & 2 \\
\hline 1023 & Bola Karet KECIL - Gaveno & Toys - Sport & $-\mathrm{NA}$ & 15.000 & 1701 & $11-06-2017$ & $\mathrm{x}$ & $21 x$ \\
\hline 1022 & Bola Karet SEDANG - Gaveno & Toys - Sport & $-\mathrm{NA}$ & 20.000 & 1701 & $11-06-2017$ & $\sqrt{ }$ & 2 \\
\hline 3147 & Dream Car Toys & Toys - Sport & Pliko & 325.000 & 1701 & $11-06-2017$ & $\sqrt{ }$ & 0 \\
\hline 199 & Fishing Games $(\mathrm{B} / \mathrm{O})$ & Toys - Sport & $-\mathrm{NA}$ & 60.000 & 1701 & 11-06-2017 & $\sqrt{ }$ & 0 \\
\hline
\end{tabular}

Gambar 9. Laporan stock opname untuk pegawai took

Gambar 9 merupakan tampilan laporan stock opname untuk pegawai toko. Pada tampilan ini terlihat mana saja produk yang sudah sesuai jumlah barangnya dan mana yang masih belum sesuai. Pegawai toko dapat melakukan perhitungan ulang pada produk di gudang dan kembali melakukan input jumlah barang. Proses ini dapat terus dilakukan berulang kali hingga jumlah sesuai.

Namun demikian setiap input yang diberikan akan tersimpan sejarahnya, sehingga baik pegawai toko maupun manajer toko dapat melihat berapa kali percobaan input sudah dilakukan. Hal ini berguna untuk menghindari kecurangan dimana pegawai toko hanya menebak jumlah barang tanpa melakukan perhitungan di gudang. 


\section{EASY POS - KA D OKIDZ

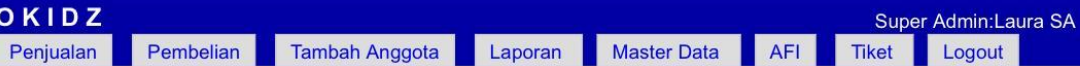

\section{Laporan Stok Opname (SO) 22-6-2017}

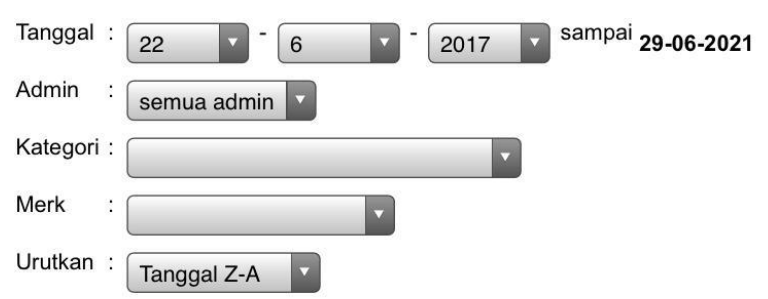

\begin{tabular}{|c|c|c|c|c|c|c|c|}
\hline Tanggal & $\begin{array}{l}\text { SO- } \\
\text { No }\end{array}$ & Admin & Kategori & Merk & $\begin{array}{c}\text { Total } \\
\text { Kesalahan }\end{array}$ & Status & Detail \\
\hline 22-06-2017 08:31 & 1740 & Yayak & BayiAcc Bedong Instant & & 0 & $\sqrt{ }$ & D \\
\hline 22-06-2017 08:32 & 1741 & Yayak & BayiAcc Bedong Standard & & 1 & $\sqrt{ }$ & D \\
\hline 22-06-2017 08:33 & 1742 & Yayak & BayiAcc Celemek Lurik & & 0 & $\sqrt{ }$ & D \\
\hline 22-06-2017 08:35 & 1743 & Yayak & BayiAcc Clody/Training Pant & & 0 & $\sqrt{ }$ & D \\
\hline 22-06-2017 08:37 & 1744 & Yayak & BayiAcc Gurita Rekat & & 1 & $\sqrt{ }$ & D \\
\hline 22-06-2017 08:42 & 1745 & Yayak & BayiAcc Gurita Tali & & 5 & $\sqrt{ }$ & D \\
\hline 22-06-2017 08:55 & 1746 & Yayak & BayiAcc Popok & & 10 & $\mathbf{x}$ & D \\
\hline 22-06-2017 09:05 & 1747 & Yayak & BayiAcc Other & & 2 & $\sqrt{ }$ & D \\
\hline 22-06-2017 09:11 & 1748 & Yayak & BayiAcc Perlak & & 2 & $\sqrt{ }$ & D \\
\hline 22-06-2017 09:14 & 1749 & Yayak & BayiAcc Sarung tangan+kaki & & 21 & $\mathbf{x}$ & D \\
\hline $22-06-2017$ 09:23 & 1750 & Yayak & BayiAcc Wash Lap & & 1 & $\sqrt{ }$ & D \\
\hline 22-06-2017 09:37 & 1751 & Yayak & BigStuff Kereta/Box & & 0 & $\sqrt{ }$ & D \\
\hline 22-06-2017 09:38 & 1752 & Yayak & BigStuff Kursi Bayi/Anak & & 1 & $\mathbf{x}$ & D \\
\hline 22-06-2017 09:58 & 1753 & Yayak & BigStuff Riding Lainnya & & 1 & $\sqrt{ }$ & D \\
\hline 22-06-2017 10:05 & 1754 & Yayak & BigStuff Riding/Baby Walker & & 0 & $\sqrt{ }$ & D \\
\hline 22-06-2017 14:39 & 1755 & Yayak & Baju Fashion Girl & & 38 & $\sqrt{ }$ & D \\
\hline 22-06-2017 15:51 & 1756 & Yayak & Baju Celana Dalam Boy & & 0 & $\sqrt{ }$ & D \\
\hline 22-06-2017 15:52 & 1757 & Yayak & Baju Celana Dalam Girl & & 0 & $\sqrt{ }$ & D \\
\hline 22-06-2017 18:07 & 1758 & Yayak & Baju Bayi Jumper/Hansof & & 9 & $\mathbf{x}$ & D \\
\hline 22-06-2017 18:31 & 1759 & Yayak & Baju Umum & & 2 & $\mathbf{x}$ & D \\
\hline
\end{tabular}

Gambar 10. Laporan stock opname untuk manajer toko

Gambar 10 merupakan tampilan laporan stock opname untuk manajer toko. Pada tampilan ini manajer toko dapat melihat kapan stock opname dilakukan, untuk kategori atau merk produk yang mana, oleh siapa dan bagaimana status serta jumlah ketidaksesuaian yang terjadi. 


\section{EASY POS - KADOKIDZ \\ PID Z \\ Pembelian Super Admin:Laura SA}

\section{Stok Opname SO-1819}

$\begin{array}{ll}\text { Admin } & : \text { Darmono } \\ \text { Tanggal } & : \text { 29-06-2021 14:35 } \\ \text { Kategori / Merk } & : \text { Toys - Sport } \\ \text { Status } & : \text { SALAH }\end{array}$

* STOK SHALL adalah stok seharusnya di sistem, pada saat SO dilakukan

\begin{tabular}{|c|c|c|c|c|c|c|c|c|c|c|}
\hline \multirow[b]{2}{*}{ Kode } & \multirow[b]{2}{*}{ Produk } & \multirow[b]{2}{*}{ Kategori } & \multirow[b]{2}{*}{ Merk } & \multirow[b]{2}{*}{ Harga } & \multicolumn{3}{|c|}{ Stok Opname Terakhir } & \multirow{2}{*}{$\begin{array}{l}\text { Stok } \\
\text { NOW }\end{array}$} & \multirow{2}{*}{$\begin{array}{c}\text { Stok } \\
\text { SHALL* }\end{array}$} & \multirow{2}{*}{$\begin{array}{l}\text { Stok } \\
\text { IS }\end{array}$} \\
\hline & & & & & $\begin{array}{l}\text { so- } \\
\text { No }\end{array}$ & Tanggal & Status & & & \\
\hline 4366 & $\begin{array}{l}\text { B/O Game Pancing } 15 \text { lkan + } 4 \\
\text { Kail }\end{array}$ & $\begin{array}{l}\text { Toys - } \\
\text { Sport }\end{array}$ & $-N A$ & 65.000 & 1701 & $\begin{array}{l}11-06- \\
2017\end{array}$ & $\sqrt{ }$ & 0 & 0 & 0 \\
\hline 3371 & Basket Ball Board Character & $\begin{array}{l}\text { Toys - } \\
\text { Sport }\end{array}$ & TLG & 65.000 & 1701 & $\begin{array}{l}11-06- \\
2017\end{array}$ & $\sqrt{ }$ & 0 & 0 & 0 \\
\hline 1021 & Bola Karet BESAR - Gaveno & $\begin{array}{l}\text { Toys - } \\
\text { Sport }\end{array}$ & $-\mathrm{NA}$ & 25.000 & 1701 & $\begin{array}{l}11-06- \\
2017\end{array}$ & $\mathbf{x}$ & 2 & 2 & 2 \\
\hline 1023 & Bola Karet KECIL - Gaveno & $\begin{array}{l}\text { Toys - } \\
\text { Sport }\end{array}$ & $-\mathrm{NA}$ & 15.000 & 1701 & $\begin{array}{c}11-06- \\
2017\end{array}$ & $x$ & -1 & -1 & $\begin{array}{l}21 \\
\times\end{array}$ \\
\hline 1022 & Bola Karet SEDANG - Gaveno & $\begin{array}{l}\text { Toys - } \\
\text { Sport }\end{array}$ & $-\mathrm{NA}$ & 20.000 & 1701 & $\begin{array}{l}11-06- \\
2017\end{array}$ & $\sqrt{ }$ & 2 & 2 & 2 \\
\hline 3147 & Dream Car Toys & $\begin{array}{l}\text { Toys - } \\
\text { Sport }\end{array}$ & Pliko & 325.000 & 1701 & $\begin{array}{l}11-06- \\
2017\end{array}$ & $\sqrt{ }$ & 0 & 0 & 0 \\
\hline 199 & Fishing Games (B/O) & $\begin{array}{l}\text { Toys - } \\
\text { Sport }\end{array}$ & $-\mathrm{NA}$ & 60.000 & 1701 & $\begin{array}{l}11-06- \\
2017\end{array}$ & $\sqrt{ }$ & 0 & 0 & 0 \\
\hline 1446 & Football Game Board & $\begin{array}{l}\text { Toys - } \\
\text { Sport }\end{array}$ & $-\mathrm{NA}$ & 160.000 & 1701 & $\begin{array}{l}11-06- \\
2017\end{array}$ & $\sqrt{ }$ & 0 & 0 & 0 \\
\hline
\end{tabular}

Gambar 11. Detail stock opname untuk manajer toko

Gambar 11 merupakan tampilan detail untuk stock opname yang sudah dilakukan oleh pegawai toko. Pada halaman ini manajer toko dapat melihat produk mana saja yang jumlahnya tidak sesuai serta berapa kali percobaan input yang sudah dilakukan oleh pegawai toko.

Manajer juga dapat melihat jumlah stok yang seharusnya di sistem dan melihat perbedaan antara jumlah yang di sistem dengan yang dimasukkan oleh pegawai toko. Selanjutnya manajer toko dapat segera mengambil keputusan terkait konsekuensi dari ketidaksesuaian jumlah barang tersebut dan kemudian mengubah jumlah barang di sistem agar jumlahnya dapat sesuai dengan kenyataan di gudang.

\section{Pengujian}

Fase berikutnya dalam penelitian ini adalah fase pengujian sistem aplikasi. Langkah pertama yang dilakukan adalah mengunggah seluruh file website dan database ke web server sehingga bisa diakses melalui web browser secara daring.

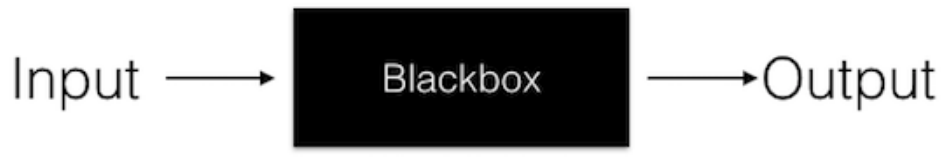

Gambar 12. Proses dalam Blackbox Testing 
Selanjutnya digunakan metode Blackbox Testing untuk menguji sistem yang sudah dibuat. Blackbox Testing ini merupakan metode yang biasa digunakan dalam pengujian perangkat lunak, dimana fokus dalam pengujian adalah apakah fungsionalitas dari setiap fitur sesuai dengan spesifikasi yang diharapkan [15][16]. Selain itu salah satu keunggulan dari teknik ini adalah dimana penguji tidak diharuskan memiliki kemampuan pemrograman. Penguji dapat merupakan pengguna awam yang memberikan input ke dalam system dan mendapatkan hasil output seperti tampak pada Gambar 12. Hasil pengujian digunakan pembuat program dalam melanjutkan proses pengembangan aplikasi [17].

Proses pengujian fungsionalitas dengan metode Blackbox Testing ini dilakukan oleh satu manajer toko dan satu pegawai toko dengan menggunakan alur proses yang sudah dioptimalkan melalui penelitian ini.

TABEL 1

Hasil Pengujian Fungsionalitas oleh Pegawai ToKo

\begin{tabular}{|c|c|c|c|}
\hline No & Skenario Pengujian & Hasil yang Diharapkan & $\begin{array}{l}\text { Hasil } \\
\text { Pengujian }\end{array}$ \\
\hline 1 & $\begin{array}{l}\text { Login ke sistem dengan hak akses } \\
\text { sebagai pegawai toko }\end{array}$ & $\begin{array}{l}\text { Login berhasil dan ditampilkan data dengan hak akses } \\
\text { sebagai pegawai toko, dimana tidak terlihat jumlah stok } \\
\text { barang }\end{array}$ & Sesuai \\
\hline 2 & $\begin{array}{l}\text { Proses stock opname dengan } \\
\text { memilih produk berdasarkan } \\
\text { kategori produk }\end{array}$ & $\begin{array}{l}\text { Ditampilkan produk sesuai dengan kategori yang dipilih } \\
\text { berikut data kapan stock opname sebelumnya dilakukan } \\
\text { untuk produk terkait }\end{array}$ & Sesuai \\
\hline 3 & $\begin{array}{l}\text { Proses stock opname dengan } \\
\text { memilih produk berdasarkan merek } \\
\text { produk }\end{array}$ & $\begin{array}{l}\text { Ditampilkan produk sesuai dengan merek yang dipilih } \\
\text { berikut data kapan stock opname sebelumnya dilakukan } \\
\text { untuk produk terkait }\end{array}$ & Sesuai \\
\hline 4 & Proses input jumlah stok & $\begin{array}{l}\text { Jumlah stok diterima dan disimpan ke dalam database } \\
\text { berikut tanggal pengisian dan } \text { user-id pegawai toko yang } \\
\text { melakukan input }\end{array}$ & Sesuai \\
\hline 5 & $\begin{array}{l}\text { Proses pencocokan jumlah stok } \\
\text { yang di-input dengan jumlah stok } \\
\text { yang tertera di sistem }\end{array}$ & Menampilkan hasil pencocokan & Sesuai \\
\hline 6 & $\begin{array}{l}\text { Proses input ulang jumlah stok yang } \\
\text { tidak sesuai }\end{array}$ & $\begin{array}{l}\text { Input ulang jumlah stok tersimpan di database berikut } \\
\text { jumlah percobaan input yang dilakukan. Juga ditampilkan } \\
\text { hasil kecocokan dari jumlah baru yang dimasukkan }\end{array}$ & Sesuai \\
\hline 7 & $\begin{array}{l}\text { Laporan proses stock opname } \\
\text { berikut informasi ketidaksesuaian } \\
\text { stok untuk pegawai toko }\end{array}$ & $\begin{array}{l}\text { Pegawai toko dapat melihat hasil laporan proses stock } \\
\text { opname yang dilakukan dan produk mana saja yang jumlah } \\
\text { stoknya tidak sesuai. Pegawai toko tidak dapat melihat } \\
\text { jumlah stok barang }\end{array}$ & Sesuai \\
\hline
\end{tabular}

Pengujian dilakukan dengan menguji beberapa skenario use case untuk pegawai toko seperti yang tertera pada Tabel 1. Pada tabel tercantum skenario apa saja yang diujikan berikut hasil yang diharapkan serta hasil pengujian. Dapat dilihat bahwa hasil pengujian sudah sesuai dengan hasil yang diharapkan dan semua fitur berfungsi sebagaimana mestinya.

TABEL 2

Hasil Pengujian Fungsionalitas OLEH MANAJER TOKO

\begin{tabular}{lll}
\hline No & Skenario Pengujian & Hasil yang Diharapkan \\
\hline 1 & $\begin{array}{l}\text { Login ke sistem dengan hak akses } \\
\text { sebagai manajer toko }\end{array}$ & $\begin{array}{l}\text { Login berhasil dan ditampilkan data dengan hak akses } \\
\text { sebagai manajer toko, dimana terlihat jumlah stok barang } \\
\text { berikut sejarah perpindahan barang }\end{array}$ \\
\hline 2 & $\begin{array}{l}\text { Laporan proses stock opname } \\
\text { berikut informasi ketidaksesuaian } \\
\text { stok untuk manajer toko }\end{array}$ & $\begin{array}{l}\text { Manajer toko dapat melihat hasil laporan proses stock } \\
\text { opname yang dilakukan dan produk mana saja yang jumlah } \\
\text { stoknya tidak sesuai. Manajer toko dapat melihat jumlah } \\
\text { stok barang serta berapa kali jumlah percobaan input stok } \\
\end{array}$ \\
\end{tabular}

Tabel 2 menunjukkan skenario pengujian yang harus dilakukan oleh manajer toko. Hasil pengujian sudah sesuai dengan yang diharapkan. Data terpenting yang dapat diperoleh dari laporan pengujian ini antara lain adalah siapa pegawai yang melakukan stock opname, kapan stock opname dilakukan, produk yang sudah sesuai jumlahnya, dan produk yang tidak 
sesuai jumlahnya. Juga dapat diketahui berapa tepatnya jumlah selisih stok serta berapa kali pegawai mencoba menghitung ulang stok produk tersebut.

\section{HASIL DAN PEMBAHASAN}

Fase berikutnya dalam penelitian ini adalah fase pengujian penerimaan aplikasi dengan menggunakan metode User Acceptance Testing (UAT). Berbeda dengan system testing sebelumnya yang menguji fungsionalitas dari aplikasi, UAT ini adalah sebuah metode untuk menguji apakah aplikasi yang dibuat bisa diterima dengan baik oleh pengguna dan dapat memenuhi kebutuhan pengguna [7][16]. UAT merupakan salah satu langkah untuk memvalidasi kesesuaian antara kebutuhan pengguna dengan aplikasi yang dihasilkan seperti tampak pada Gambar 13. Hasil dari UAT ini akan menunjukkan apakah fungsionalitas dari aplikasi diterima sepenuhnya, diterima dengan revisi atau tidak diterima oleh pengguna [17].

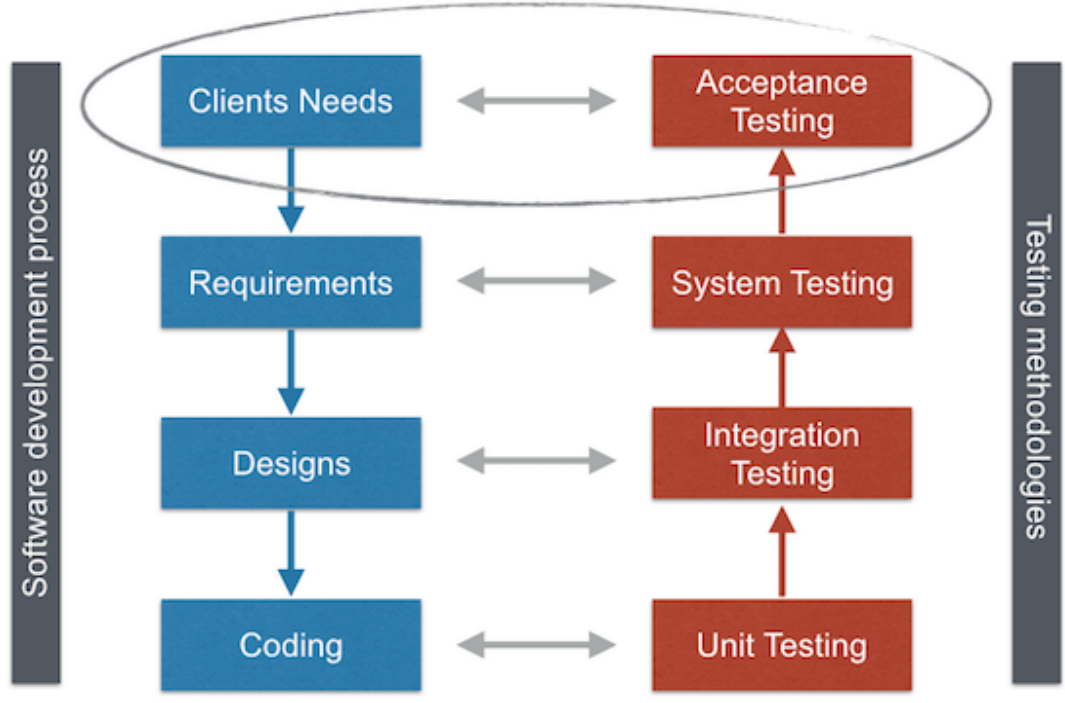

Gambar 13. Kaitan antara Software Development Process dan Testing Methodologies [18]

Proses pengujian UAT ini dimulai dengan membuat pertanyaan kuesioner berdasarkan hasil analisis di awal penelitian, sehingga dapat dipastikan bahwa fitur yang dibuat sesuai dengan kebutuhan. Pilihan jawaban serta bobot penilaian dari pertanyaan kuesioner ini dapat dilihat pada Tabel 3.

TABEL 3

PILIHAN JAWABAN DAN Bobot PENILAIAN UAT

\begin{tabular}{ccc}
\hline Pilihan Jawaban & \multicolumn{1}{c}{ Keterangan } & Bobot Penilaian \\
\hline A & Sangat Mudah/Bagus/Sesuai/Jelas & 5 \\
\hline B & Mudah/Bagus/Sesuai/Jelas & 3 \\
\hline C & Netral & 2 \\
\hline D & Cukup Sulit/Bagus/Sesuai/Jelas & 1 \\
\hline E & Sangat Sulit/Bagus/Sesuai/Jelas & \\
\hline
\end{tabular}

Pada Tabel 4 dapat dilihat pertanyaan kuesioner yang diberikan kepada responden serta berapa jumlah responden yang memberikan jawaban untuk setiap pilihan jawaban. Responden yang ikut serta dalam proses ini adalah 7 orang yang terdiri atas 2 orang manajer toko dan 5 orang pegawai toko. 
TABEL 4

PERTANYAAN KUESIONER UAT DAN JUMLAH JAWABAN

\begin{tabular}{|c|c|c|c|c|c|c|}
\hline \multirow[t]{2}{*}{ No } & \multirow[t]{2}{*}{ Pertanyaan } & \multicolumn{5}{|c|}{ Jumlah Jawaban } \\
\hline & & $\mathbf{A}$ & B & C & D & $\mathbf{E}$ \\
\hline 1 & $\begin{array}{l}\text { Apakah aplikasi mempermudah tugas Anda dalam melakukan } \\
\text { stock opname? }\end{array}$ & 2 & 3 & 2 & & \\
\hline 2 & $\begin{array}{l}\text { Apakah aplikasi mempersingkat waktu Anda untuk } \\
\text { menyelesaikan proses stock opname? }\end{array}$ & 5 & 2 & & & \\
\hline 3 & $\begin{array}{l}\text { Apakah stock opname dapat dilakukan lebih sering dari } \\
\text { sebelumnya? }\end{array}$ & 7 & & & & \\
\hline 4 & $\begin{array}{l}\text { Apakah stock opname dapat dilakukan tanpa menghentikan } \\
\text { operasional penjualan? }\end{array}$ & 1 & 3 & 3 & & \\
\hline 5 & $\begin{array}{l}\text { Apakah proses stock opname dapat dilakukan tanpa kehadiran } \\
\text { manajer? }\end{array}$ & 3 & 4 & & & \\
\hline 6 & $\begin{array}{l}\text { Apakah alur proses pada aplikasi mencegah untuk terjadinya } \\
\text { kecurangan dalam proses stock opname? }\end{array}$ & 2 & 3 & 1 & 1 & \\
\hline 7 & $\begin{array}{l}\text { Apakah informasi dari laporan stock opname mempercepat Anda } \\
\text { dalam mengambil keputusan bisnis dan mengambil tindakan? }\end{array}$ & 5 & 1 & 1 & & \\
\hline 8 & Apakah panduan proses stock opname mudah dipahami? & 3 & 2 & 2 & & \\
\hline 9 & Apakah tampilan dan struktur aplikasi mudah dipahami? & 3 & 4 & & & \\
\hline 10 & Apakah aplikasi mudah dioperasikan? & 5 & 2 & & & \\
\hline 11 & Apakah aplikasi dapat diakses dengan lancar melalui internet? & 7 & & & & \\
\hline 12 & $\begin{array}{l}\text { Apakah alur proses stock opname mendukung penyelesaian tugas } \\
\text { Anda lainnya? }\end{array}$ & 2 & & 5 & & \\
\hline 13 & $\begin{array}{l}\text { Apakah Anda akan menggunakan aplikasi ini untuk melakukan } \\
\text { stock opname? }\end{array}$ & 6 & & 1 & & \\
\hline
\end{tabular}

Data yang diperoleh dari pengisian kuesioner kemudian diolah seperti yang terlihat pada Tabel 5. Pengolahan data dilakukan dengan cara mengalikan antara jumlah jawaban yang diterima dengan bobot penilaian untuk setiap jawaban, kemudian hasil perkalian dihitung persentasenya.

Dari hasil pengolahan ini diperoleh ada 2 jawaban yang bernilai tertinggi yaitu $100 \%$ pada pertanyaan terkait meningkatnya frekuensi pelaksanaan proses stock opname dan kemudahan akses aplikasi melalui internet.

Pada urutan kedua senilai 94\% diperoleh dari tiga jawaban pada pertanyaan terkait kemudahan pengoperasian aplikasi, waktu pelaksanaan stock opname yang dipersingkat dan pertanyaan apakah responden akan melanjutkan menggunakan aplikasi untuk melakukan stock opname.

Berikutnya dengan nilai 91\% diperoleh dari pertanyaan terkait kecepatan pengambilan keputusan berdasarkan informasi yang diperoleh dari laporan di aplikasi.

Pada pertanyaan apakah pelaksanaan stock opname dapat dilakukan tanpa kehadiran manajer dan apakah tampilan/struktur aplikasi mudah dipahami diperoleh nilai 89\%. Panduan pelaksanaan proses stock opname mendapatkan nilai $83 \%$. Nilai $80 \%$ diperoleh untuk pertanyaan apakah aplikasi mempermudah responden untuk melakukan proses stock opname.

Nilai 77\% diberikan untuk pertanyaan terkait pencegahan kecurangan pada saat pelaksanaan stock opname. Hasil ini menunjukkan bahwa responden berpendapat bahwa kecurangan masih ada kemungkinan terjadi selama proses stock opname.

Nilai $74 \%$ diberikan untuk pertanyaan apakah proses stock opname dapat dilakukan tanpa menghentikan proses operasional penjualan. Hasil ini berdasarkan pelaksanaan stock opname di lapangan yang membutuhkan waktu 1-2 jam setiap kalinya. Meskipun demikian responden menyatakan durasi 1-2 jam ini sangat bisa ditoleransi mengingat sebelumnya mereka membutuhkan waktu 1-2 hari untuk pelaksanaan stock opname.

Nilai terendah $71 \%$ diperoleh untuk pertanyaan apakah alur proses stock opname mendukung penyelesaian tugas lain. Responden dengan hak akses pegawai toko menyatakan bahwa alur proses system yang baru dimana mereka tidak lagi bisa melihat jumlah stok yang tercantum di system kadang menghambat pekerjaan mereka. Ada kalanya mereka perlu melihat jumlah stok yang masih tersedia pada saat melayani pembeli.

Hasil total nilai rata-rata dari pengujian UAT ini adalah $87 \%$ yang menunjukkan bahwa responden merasa cukup puas dan aplikasi yang dibuat cukup dapat menjawab kebutuhan mereka. 
TABEL 5

PENGOLAhan DATA KuEsioner UAT

\begin{tabular}{|c|c|c|c|c|c|c|c|c|}
\hline \multirow[t]{2}{*}{ No } & \multirow[t]{2}{*}{ Pertanyaan } & \multicolumn{5}{|c|}{ Subtotal Nilai } & \multirow{2}{*}{$\begin{array}{l}\text { Total } \\
\text { Nilai }\end{array}$} & \multirow{2}{*}{$\begin{array}{l}\text { Persentase } \\
\quad \text { Nilai }\end{array}$} \\
\hline & & $\mathbf{A}$ & B & $\mathbf{C}$ & D & $\mathbf{E}$ & & \\
\hline 1 & $\begin{array}{l}\text { Apakah aplikasi mempermudah tugas Anda } \\
\text { dalam melakukan stock opname? }\end{array}$ & 10 & 12 & 6 & & & 28 & $80 \%$ \\
\hline 2 & $\begin{array}{l}\text { Apakah aplikasi mempersingkat waktu Anda } \\
\text { untuk menyelesaikan proses stock opname? }\end{array}$ & 25 & 8 & & & & 33 & $94 \%$ \\
\hline 3 & $\begin{array}{l}\text { Apakah stock opname dapat dilakukan lebih } \\
\text { sering dari sebelumnya? }\end{array}$ & 35 & & & & & 35 & $100 \%$ \\
\hline 4 & $\begin{array}{l}\text { Apakah stock opname dapat dilakukan tanpa } \\
\text { menghentikan operasional penjualan? }\end{array}$ & 5 & 12 & 9 & & & 26 & $74 \%$ \\
\hline 5 & $\begin{array}{l}\text { Apakah proses stock opname dapat } \\
\text { dilakukan tanpa kehadiran manajer? }\end{array}$ & 15 & 16 & & & & 31 & $89 \%$ \\
\hline 6 & $\begin{array}{l}\text { Apakah alur proses pada aplikasi mencegah } \\
\text { untuk terjadinya kecurangan dalam proses } \\
\text { stock opname? }\end{array}$ & 10 & 12 & 3 & 2 & & 27 & $77 \%$ \\
\hline 7 & $\begin{array}{l}\text { Apakah informasi dari laporan stock opname } \\
\text { mempercepat Anda dalam mengambil } \\
\text { keputusan bisnis dan mengambil tindakan? }\end{array}$ & 25 & 4 & 3 & & & 32 & $91 \%$ \\
\hline 8 & $\begin{array}{l}\text { Apakah panduan proses stock opname } \\
\text { mudah dipahami? }\end{array}$ & 15 & 8 & 6 & & & 29 & $83 \%$ \\
\hline 9 & $\begin{array}{l}\text { Apakah tampilan dan struktur aplikasi } \\
\text { mudah dipahami? }\end{array}$ & 15 & 16 & & & & 31 & $89 \%$ \\
\hline 10 & Apakah aplikasi mudah dioperasikan? & 25 & 8 & & & & 33 & $94 \%$ \\
\hline 11 & $\begin{array}{l}\text { Apakah aplikasi dapat diakses dengan lancar } \\
\text { melalui internet? }\end{array}$ & 35 & & & & & 35 & $100 \%$ \\
\hline 12 & $\begin{array}{l}\text { Apakah alur proses stock opname } \\
\text { mendukung penyelesaian tugas Anda } \\
\text { lainnya? }\end{array}$ & 10 & & 15 & & & 25 & $71 \%$ \\
\hline 13 & $\begin{array}{l}\text { Apakah Anda akan menggunakan aplikasi } \\
\text { ini untuk melakukan stock opname? }\end{array}$ & 30 & & 3 & & & 33 & $94 \%$ \\
\hline
\end{tabular}

\section{SIMPULAN}

Hasil dan pembahasan dalam penelitian ini menunjukkan bahwa solusi yang dirancang dapat mengatasi permasalahan yang dikemukakan di fase analisis. Solusi berupa perubahan alur sistem stock opname yang tidak lagi menampilkan jumlah stok kepada pegawai toko dan hanya memberikan notifikasi status kesesuaian jumlah stok terbukti dapat menjawab kebutuhan responden.

Proses stock opname kini dapat dilakukan tanpa kehadiran pemilik bisnis / manajer toko, sehingga dapat mengurangi biaya operasional atau biaya akomodasi. Manajer toko dapat melihat hasil laporan segera setelah proses stock opname selesai dilakukan dan dapat melihat produk apa saja yang tidak sesuai stok dan detail jumlahnya. Selain itu manajer toko juga dapat melihat sejarah stock opname serta siapa pegawai yang melakukan stock opname. Proses stock opname kini juga dapat dilakukan tanpa perlu menghentikan seluruh operasional penjualan di lokasi toko. Karena itu frekuensi pelaksanaan dapat ditingkatkan dari yang awalnya hanya dilakukan 2-3 kali dalam setahun.

Perubahan otomatisasi proses stock opname ini juga telah diuji dengan metode Blackbox Testing dan User Acceptance Testing dengan hasil yang menunjukkan bahwa keseluruhan fitur aplikasi berfungsi dengan baik dan responden memberikan nilai UAT sebesar $87 \%$ yang artinya mereka menerima bahwa aplikasi dapat memberikan solusi bagi permasalahan mereka sebelumnya.

\section{DAFTAR PUSTAKA}

[1] E. Wince, "Kajian Pentingnya Stock Opname Dalam Pengembangan Koleksi Perpustakaan." Tik Ilmeu : Jurnal Ilmu Perpustakaan dan Informasi, vol. 1, no 1,pp 79-88, Jun. 2017.

[2] D. Supriyadi, R. Nuzulah, \& M. Hermawati, "Aplikasi Inventori Stok Opname Barang Di Pt. Indomarco Prismatama Cabang Bogor". Seminar Nasional Riset dan Teknologi, vol. 5, no. 1, pp.121-125, Jan. 2021.

[3] O. Irnawati, "Implementasi Metode Waterfall Pada Sistem Informasi Stock Opname", Indonesian Journal on Software Engineering, vol. 4, no.1, pp.79-84, 2018 
[4] G. Khasani, \& D. Surjawan, "Aplikasi Inventory Berbasis Web Pada PT Telkomsel NS Tasikmalaya". Jurnal Teknik Informatika Dan Sistem Informasi, vol. 2, no. 3, pp. 319-330, Dec. 2016

[5] G. Sastrawangsa, N.K. Sumiari \& I.G.V.M. Karuna, "Otomatisasi Stock Opname pada Senayan Library Management System". Computer Science Research and Its Development Journal, vol 12, no 1, pp. 42-50, Feb. 2020

[6] A. Purwantinah, "The Improvement of the Ability to Perform Steps of Stock Opname Using Demonstration Method". Ideguru: Jurnal Karya Ilmiah Guru, vol. 5, no. 2, pp.20-28, Nov. 2020

[7] T. Rafliana \& B. Suteja, "Penerapan Metode EOQ dan ROP untuk Pengembangan Sistem Informasi Inventory Bengkel MJM berbasis Web", Jurnal Teknik Informatika Dan Sistem Informasi, vol. 4, no. 2, pp. 345-354, Aug. 2018.

[8] Rosa A. S \& M. Shalahuddin, Rekayasa Perangkat Lunak: Terstruktur dan Berorientasi Objek. Informatika Bandung, 2014.

[9] J. Simarmata \& I.Prayudi, Basis Data, Yogyakarta: ANDI, 2006.

[10] B. Swartz, P. Zaitsev \& V. Tkachenko, High Performance MySQL: Optimization, Backups, and Replication, Third Edition, O'Reilly Media, 2012.

[11] J. Yonata (2021) Dewaweb Homepage. [Online]. Tersedia: https://www.dewaweb.com/blog/apa-itu-mysql/\#Fungsi_dan_Penerapan_MySQL

[12] J. Robbins, Learning Web Design: A Beginner's Guide to HTML, CSS, JavaScript, and Web Graphics, 5th Edition, O'Reilly Media, 2018

[13] K. Tatroe \& P. MacIntyre, Programming PHP: Creating Dynamic Web Pages, 4th edition, O'Reilly Media, 2020

[14] M.Robith Adani (2021) Sekawan Media Homepage. [Online]. Tersedia: https://www.sekawanmedia.co.id/pengertian-php/

[15] T.S. Jaya, "Pengujian Aplikasi dengan Metode Blackbox Testing Boundary Value Analysis (Studi Kasus: Kantor Digital Politeknik Negeri Lampung)", Jurnal Informatika: Jurnal Perngembangan IT (JPIT), vol 3, no 2, pp.45-48, Jan. 2018

[16] K. Naik, P. Tripathy, Software Testing and Quality Assurance: Theory and Practice, Hoboken, New Jersey: John Wiley \& Sons, 2008.

[17] P. Ammann \& J. Offutt, Introduction to Software Testing Edition 2, Instructor Version. pp. 2002-2009, 2016

[18] T. Peham (2021) Usersnap. [Online]. Tersedia: https://usersnap.com/blog/types-user-acceptance-tests-frameworks/ 